2017

\title{
Comparative review of education doctorates in three Countries..
}

\author{
East, M
}

http://hdl.handle.net/10026.1/6604

\section{IGI Global}

All content in PEARL is protected by copyright law. Author manuscripts are made available in accordance with publisher policies. Please cite only the published version using the details provided on the item record or document. In the absence of an open licence (e.g. Creative Commons), permissions for further reuse of content should be sought from the publisher or author. 


\section{Reference for In-Press Article:}

East, M. L., Hajdukova, E. B., Carr, M. E., Evans, W. H., \& Hornby, G. (In press, 2017). Comparative review of education doctorates in three Countries, in Exploring the Future of Accessibility in Higher Education, by H. Alphin Jr., J. Lavine, \& R. Chan (Eds.), Hershey, PA: IGI Global.

\section{Comparative Review of Education Doctorates in Three Countries}

Marlene L. East ${ }^{1}$, Eva Brown Hajdukova ${ }^{2}$, Monica E. Carr ${ }^{3}$, William H. Evans ${ }^{4} \&$ Garry Hornby ${ }^{5}$

${ }^{1}$ College of Education and Professional Studies, The University of West Florida, Pensacola, Florida, USA; East Counseling Services, Inc., Panama City Beach, Florida, USA

${ }^{2}$ Faculty of Education, University of Cambridge, Cambridge, UK

${ }^{3}$ Faculty of Education, Monash University, Melbourne, Australia

${ }^{4}$ Teacher Education and Educational Leadership, The University of West Florida, Pensacola, Florida, USA

${ }^{5}$ Institute of Education, Plymouth University, Plymouth, UK

Correspondence: Marlene L. East, East Counseling Services, Inc. 6521 North Lagoon Drive, Panama City Beach, FL 32408, USA. drmarleneeast@gmail.com. Tel: 850-250-2690.

\section{ABSTRACT}

Researchers affiliated with education $\mathrm{PhD}$ programs in Australia and New Zealand, and an education EdD program in the United States aimed to enhance understanding of contemporary education doctorate approaches and challenges. The central research question was: What knowledge will emerge regarding education doctoral programs through the lens of globalization? Using a descriptive interpretive research paradigm, collaborators determined that although education doctorate approaches vary, skills developed are similar. As researchers are increasingly viewed as strategic assets, access to quality education is essential. Doctoral program planners must attend to the paradigm shift away from traditional apprenticeship supervision pedagogy to structured and standardized approaches. For sustainability, online education must be integrated into doctoral programs, while ensuring faculty are trained in distance education theory and best practices. As growth in doctoral enrollments drives the need for more faculty, program planners must also aim to solve related problems of contingent academic labor.

\section{KEYWORDS}

Accessibility, Competencies, Contingent Labor, Digital Transformation, Globalization, Higher Education, Monash University, Online Education, University of Canterbury, University of West Florida 


\section{INTRODUCTION}

New knowledge generation has been described as a significant strategic resource that impacts a country's economy (Kirshin, 2014; Salmi, 2000). Countries that fail to provide a well-trained cadre of higher education professionals who are able to match the exponential growth in knowledge face the risk of falling behind in education, production, and economic viability (Organization for Economic Cooperation and Development [OECD], 2012). Continual advances in transportation, communication, and related infrastructure such as the Internet, drive globalization, and further the interdependence of economies and cultures. In this digital era and increasingly integrated world market (Salmi, 2000) technology advances the pace of learning, with knowledge changing at an accelerating rate (Haggans, 2015; Jamieson \& Naidoo, 2007). Haggans indicates that the digital transformation is altering every aspect of universities. A rapid evolution is taking place in residence halls, libraries, pedagogy, textbooks, course delivery, and uses of facilities. Digital transformation requires countries to produce highly educated critical thinkers, researchers, and planners who are equipped to maximize resources for sustainable higher education and who are able to address contemporary issues (Nerad, 2012). This need for scholars also raises pressing issues regarding accessibility to higher education.

In view of this early 21 st century setting, the $\mathrm{PhD}$ tradition has inescapably faced challenges to improve efficiency and effectiveness (Thelin, 2013). In many countries professional doctorate programs evolved as an alternative training pathway (Kot \& Hendel, 2012). Kot and Hendel described the proliferation of professional doctorates in the United States, United Kingdom and Australia as remarkable. Further, Kot and Hendel note that while a number of studies investigated doctoral training in the United Kingdom and Australia, there is a dearth of studies on the emergence of professional doctorate programs in the United States and Canada. Higher educational training in Australia has been acknowledged as based upon the U.K. system.

Blackstone (2012) describes macro, meso, and micro approaches to sociological inquiry. According to Blackstone, macrolevel research investigates interactions between nations or comparisons across nations, mesolevel research investigates interactions between groups, and microlevel research investigates the smallest levels of interaction. Accordingly, at a macro level across nations, this study compares contemporary doctoral training programs grounded in both U.K. based and U.S. based approaches. At a micro level regarding fields of study, this research project is limited to contemporary doctorates conferred as the highest degrees for educators, education doctorates. Spotlighting in an exploratory study the commonalities and differences in education doctorate programs offers contemporary insights regarding approaches to and accessibility of doctoral education. A goal for this exploration is to determine the need for and feasibility of more extensive research that will serve to inform doctoral program planning and related policy enhancements. A purposeful sample reflecting the lived experiences of three of the authors, recent education doctoral graduates in Australia, New Zealand, and the United States, informed this study. A literature review regarding doctoral degree approaches in general along with an explanation of education doctorates forms the background for the study. The central research question guiding the investigation was: What knowledge will emerge regarding contemporary education doctoral programs' approaches and accessibility through the lens of globalization? 


\section{LITERATURE REVIEW}

\section{Doctoral Degree Approaches}

The traditional Philosophiae Doctor (PhD) emerged from European medieval universities (Huisman and Naidoo, 2006) and various types of doctorate degrees evolved over time in response to cultural changes, globalization, and criticisms of the nature of the traditional $\mathrm{PhD}$ (Nerad, 2004). A trend toward the professionalization of faculty as subject experts also emerged and led to development of professional associations, academic journals, tenure, rank and promotion (Harris, 2013). In a history of the evolution of doctorate degrees, Huisman and Naidoo (2006) state that the main distinction between types of doctoral degrees is the presence of either an academic or a professional orientation. Regarding the latter orientation, Wellington and Sikes (2006), indicate much variation. By combining findings from an investigation of professional doctorates in business, engineering, and education (Scott, Brown, Lunt, \& Thorne, 2004), with findings from their own qualitative study of students seeking Doctorate of Education (EdD) degrees at University of Sheffield in the United Kingdom, Wellington and Sikes propose a spectrum or continuum of professional doctorates. Scott et al.'s study along with Wellington and Sikes findings indicate much diversity in professional doctorates' pedagogical formats, student motivations and timing for pursuing doctorates, and impact on personal and professional lives of graduates.

Along the spectrum of contemporary doctoral approaches are a variety of relevant but often overlapping terms. Under traditional $P h D$ training, the student typically works alone on a dissertation as an apprentice supervised by one or two senior researchers (Flores, 2011; Huisman \& Naidoo, 2006; Nerad, 2012). The apprenticeship model has been described by Golde and Dore (2001) as a method in which students learn the intricacies of research necessary to become independent scholars. The $P h D$ by publication is similar to the traditional $\mathrm{PhD}$, however, the thesis includes a number of published papers or chapters that link to the central research question. A taught doctorate includes coursework and formal assessment. Scott et al. (2004) indicate taught elements in doctoral programs are steadily becoming the norm. A work-based or practice-based doctorate is earned in creative and performing arts, design, and health. The professional doctorate in a professional rather than academic field of study, is generally a taught doctorate that includes coursework and assessment with a focus on application within the student's professional practice.

In a discussion of the growth of professional doctorates in the United States, United Kingdom, Canada, and Australia, Kot and Hendel (2012) indicate that although there is no consistent definition of a professional doctorate across countries, there is a strong growth trend in these types of degrees. According to the Survey of Earned Doctorates website, the professional doctorate was recognized as one of 18 U.S. research doctorates equivalent to the $\mathrm{PhD}$ in the 2013 survey. Kot and Hendel note the $\mathrm{PhD}$ remains the most popular doctorate in the United States but that the number of professional doctorate awards continues to increase.

\section{Higher Education Doctorate Degrees}

According to Perry (2016) the EdD was created at Harvard College in 1921 and eighty years later, there has been little understanding in the distinction between the PhD and the EdD. Similarly, Guthrie and Clifford (1989) describe the search for legitimacy in education as a social science against the backdrop of reluctance of older disciplines to view higher education as a field. Carter also (1994) traces the 
development of U.S. tensions between the award of the education $\mathrm{PhD}$ and the EdD. Carter demonstrates how dissatisfaction with education administrator preparation and a corresponding need for high-quality leadership led to widespread educational reform. The reforms ultimately influenced the emergence of a spectrum of U.S. approaches to doctoral education. Carter further illustrates how the reforms evolved into a preference for the EdD. With its professional orientation, the EdD is designed to prepare educational leaders for the real world of practice. According to Carter, by the late $20^{\text {th }}$ century, unlike the established fields of medicine, law, and engineering, there had been little effort toward developing theory of practice in educational administration. More recently, however, Card, Chambers, and Freeman (2016) indicate a maturation in the study of higher education and describe it as a multidisciplinary field that has the potential to transition to being respected as an academic discipline.

Card et al. (2016) reviewed the history of coursework requirements in higher education doctoral programs and surveyed doctoral education program directors to gain a sense of the current coursework landscape. The researchers indicate both the $\mathrm{PhD}$ and the $\mathrm{EdD}$ are offered in the field of education and that both types of doctorates in the United States require coursework. Historically, the researchers note courses in organization, leadership, and administration have been commonly taught along with history of education. Philosophy, governance, and multiculturalism were found most often to be embedded in other courses instead of taught as separate courses. Card et al. note a growing emphasis on student affairs, student development, and research along with the surfacing of law and finance in contemporary core curriculum requirements.

A reform agenda by The National Policy Board for Educational Administration ([NPBEA], 1989) gave rise to national standards along with certification and licensure requirements for school administrators with the EdD often being a prerequisite. According to a study by Hackman (2016), while many U.S. states have adopted standards and licensure requirements for educational leaders, significant variation exists in licensure regulations, curriculum and internship requirements, and test requirements. Notably, Hackman found that licensure regulations were generally consistent across the United States in other fields such as medicine, law, psychology, and engineering.

Higher education doctorate training continues to be enhanced and reformed through policies and standards. In view of the global economy, the digital transformation, and changing demographics, NPBEA (2015) for example, updated 1996 and 2008 U.S. standards with the publication, Professional Standards for Educational Leaders 2015. The emphasis of the latest standards is to prepare leaders to ensure that students are equipped for the $21^{\text {st }}$ century. Other important contributions to education doctorate programs are being advanced by the Carnegie Project on the Education Doctorate (CPED). Perry (2016) indicates that CPED is a network of education faculty that was formed in 2007 that aims to meet the needs of practitioner-scholar students by differentiating the EdD from the PhD. Perry describes CPED as an action-oriented effort that is changing the meaning and design of the EdD. CPED has tripled in size and has 86 schools who are members including two in Canada and one in New Zealand. 


\section{RESEARCH METHOD AND PARTICIPANTS}

With the doctorate being the highest degree awarded in education, it is useful to develop understanding regarding how universities are approaching education doctorate programs in relation to the theoretical framework of globalization, a complex integration of capital, technology, and information across national boundaries (Salmi, 2000). In order to gain such insight, a group of five researchers (referred to collectively as collaborators), collaborated via video conferencing and digital file sharing over the course of two years (2014-2016). According to Berg and Lune (2012) qualitative research offers rich, detailed descriptions of a phenomena. The collaborators therefore selected a qualitative descriptive interpretive research approach (Sandelowski, 2000) as the most appropriate method to guide an exploratory study comparing the phenomena of contemporary education doctorate approaches in the globalization era. Sandelowski makes a strong case for the value of descriptive interpretive research that draws from naturalistic inquiry. Referencing Wolcott's (1994) ethnography of experiences as a principal, Sandelowski asserts that in qualitative approaches researchers often study familiar topics, immerse themselves into research settings, and apply personal observations and interpretations to convey meanings.

Likewise, collaborators in this comparative review of education doctorates across three countries drew from the familiarity of their respective education doctorate programs. This approach provides a descriptive lens for discussing, comparing, and inferring meanings. As themes surfaced through periodic real-time video chats and email correspondence, collaborators searched literature for related research. To align with the chosen research approach, collaborators aimed for descriptive validity (Sandelowski, 2000) in providing background research and in accurately describing the three doctoral programs. Collaborators also aimed for interpretive validity (Sandelowski, 2000) by connecting interpretations of themes that emerged to existing higher education research.

Regarding sampling of participants for this comparative review, purposeful sampling was the method selected. Etikan, Abubakar, \& Alkassim (2016) indicate purposeful sampling is often used in qualitative research and does not require a set number of participants. They further indicate that purposeful sampling requires knowledgeable participants who represent the phenomenon of interest, who are willing and available to participate, and who are able to articulately and reflectively communicate experiences and opinions. Accordingly, a purposeful sample was drawn from existing affiliations between teacher education faculty at three higher education institutions. Education doctorate faculty members were asked to participate and to nominate qualified doctoral candidates. Following an informational video conference meeting with a dozen attendees, three doctoral candidates and two professors chose to participate in the research project. Collaborators included a doctoral candidate in an education $\mathrm{PhD}$ program at Monash University in Australia, a doctoral candidate and professor in an education $\mathrm{PhD}$ program at University of Canterbury in New Zealand, and a doctoral candidate and professor in an education EdD program at The University of West Florida in the United States. The three doctoral candidates were each conferred education doctorate degrees during the course of this project and are referred to collectively as recent education doctorate graduates (REDGs) and individually as REDG from each country: Australia (REDGAU), New Zealand (REDG-NZ) and United States (REDG-US). 
Two of the participants (REDG-AU and REDG-US) chose to pursue degrees from institutions in their respective home countries. REDG-AU desired course content relevant to her country of origin as well as content with global implications. REDG-US resides in a small town with no doctoral programs. The emergence of online education offered REDG-US a long-awaited opportunity to pursue a doctorate degree. REDG-NZ, from Slovakia, chose to study abroad, having located two doctoral program supervisors with the desired expertise and research interests. Discovering a new culture and gaining exposure to differing research perspectives were valued by REDG-NZ as a means of enhancing personal development and internationalizing her curriculum vitae. All three REDGs indicated program costs, funding availability, format, and accessibility were considerations in choosing doctoral programs. Program duration was another consideration in doctoral program selection and all three REDGs earned degrees in less than four years.

\section{COMPARISON OF THREE CONTEMPORARY EDUCATION DOCTORATES}

At first glance, comparing two $\mathrm{PhD}$ programs with an EdD program may seem incongruous and perhaps inconsequential. Each of the three programs explored, however, confer terminal degrees in the field of education, education doctorates. Moreover, Thurgood, Golladay, and Hill (2006) indicate that two of the most common education doctorates are the $\mathrm{PhD}$ and the $\mathrm{EdD}$. Collaborators agreed that comparing doctoral approaches across borders is expedient in this era of globalization and the associated burgeoning worldwide demand for higher education. The researchers compared the three education doctorate programs in terms of cost, admission requirements, time requirements, form, and milestone assessments (Table 1). Enrollment data from each university is compared in Table 2. General information about each university is provided along with specifics about the doctoral programs. 
Table 1

Comparison of contemporary doctoral degrees in three countries in 2015: Australia, New Zealand, and United States

\begin{tabular}{|c|c|c|c|}
\hline & $\begin{array}{c}\text { PhD Monash Univ. } \\
\text { Australia }\end{array}$ & $\begin{array}{l}\text { PhD Univ. of Canterbury } \\
\text { New Zealand }\end{array}$ & $\begin{array}{c}\text { EdD Univ. of West FL } \\
\text { United States }\end{array}$ \\
\hline Tuition Cost ${ }^{1}$ & $\$ 58,658-\overline{\$ 76,898^{2}}$ & $\$ 14,375 \overline{-\$ 19,166^{3}}$ & $\$ 25,000-\$ 68,000 \mathrm{USD}^{4}$ \\
\hline $\begin{array}{l}\text { Scholarships } \\
\text { Available }\end{array}$ & $\checkmark$ & $\checkmark$ & $\checkmark$ \\
\hline $\begin{array}{l}\text { Admissions } \\
\text { Requirements }\end{array}$ & $\begin{array}{l}\text { - Demonstrated ability to } \\
\text { conduct research } \\
\text { - Bachelor's degree with } \\
\text { research component } \\
\text { - Graduate degree with } \\
\text { research component \& } \\
\text { Honours Level } 2 \text { average } \\
\text { grades, or, publications in } \\
\text { scholarly journals } \\
\text { - Demonstrated English } \\
\text { proficiency }\end{array}$ & $\begin{array}{l}\text { - Bachelor's or Master's } \\
\text { Degree with } 1^{\text {st }} \text { or } 2^{\text {nd }} \text { class } \\
\text { honours } \\
\text { - Independent research } \\
\text { project or dissertation } \\
\text { completed in previous } \\
\text { degree program } \\
\text { - Or, demonstrated ability to } \\
\text { pursue PhD degree } \\
\text { - Demonstrated English } \\
\text { proficiency }\end{array}$ & $\begin{array}{l}\text { - Master's degree with } \\
\text { 3.0+ GPA } \\
\text { - Letters of } \\
\text { recommendation } \\
\text { - Goal statement } \\
\text { - Graduate Record Exam } \\
\text { (GRE) combined score } \\
\text { of } 1000 \text { or other } \\
\text { acceptable graduate } \\
\text { admissions test }\end{array}$ \\
\hline $\begin{array}{l}\text { Time Permitted } \\
\text { to Complete }\end{array}$ & $\begin{array}{l}3-4 \text { Years Full-Time; } 6-8 \\
\text { Years Part-Time }\end{array}$ & $2-5$ Years & $3-7$ Years \\
\hline $\begin{array}{l}\text { Average } \\
\text { Completion } \\
\text { Time }\end{array}$ & $3-4$ Years & 4 Years & 4 Years \\
\hline Form & $\begin{array}{l}\text { - Traditional academically } \\
\text { focused research degree } \\
\text { - Apprenticeship model }\end{array}$ & $\begin{array}{l}\text { - Traditional academically } \\
\text { focused research degree } \\
\text { - Apprenticeship model }\end{array}$ & $\begin{array}{l}\text { - Traditional academically } \\
\text { focused research degree } \\
\text { - Combination of taught } \\
\text { doctorate, professional } \\
\text { doctorate, and } \\
\text { apprenticeship }\end{array}$ \\
\hline $\begin{array}{l}\text { Milestone } \\
\text { Assessments }\end{array}$ & $\begin{array}{l}\text { - At } 1 \text { year: Doctoral } \\
\text { upgrade report and } \\
\text { presentation to faculty } \\
\text { panel } \\
\text { - Mid-candidature progress } \\
\text { report and presentation } \\
\text { - Pre-submission } \\
\text { presentation of thesis } \\
\text { - Thesis: traditional or with } \\
\text { publications }\end{array}$ & $\begin{array}{l}\text { - } 6 \text { months post- } \\
\text { enrollment: Research } \\
\text { proposal \& supervisory } \\
\text { agreement } \\
\text { - Every } 6 \text { months: formal } \\
\text { documentation of } \\
\text { progress } \\
\text { - Thesis and oral defense } \\
\text { of thesis }\end{array}$ & $\begin{array}{l}\text { - Objective tests, graded } \\
\text { projects, graded research } \\
\text { papers in each course } \\
\text { - Preliminary examination } \\
\text { \& oral defense of } \\
\text { responses upon } \\
\text { completion of } \\
\text { coursework } \\
\text { - Oral defense of } \\
\text { dissertation proposal } \\
\text { - Dissertation and oral } \\
\text { defense of dissertation }\end{array}$ \\
\hline
\end{tabular}

\footnotetext{
${ }^{1}$ Figures are approximate and represent only tuition costs; based on 2015 figures; shown in USD (XE Currency Converter, April 27, 2015).

${ }^{2}$ Represents a 3-4 year enrollment.

${ }^{3} \$ 4,852$ USD per year for $2-4$ years.

${ }^{4}$ Range represents tuition for FL residents to out-of-state residents. Cost represents tuition only for a minimum requirement of 66 credit hours, which is completed in 3-5 years.
} 
Table 2

Comparison of Enrollments at Monash University, Australia, University of Canterbury, New Zealand, and The University of West Florida, United States.

\begin{tabular}{|c|c|c|c|}
\hline & $\begin{array}{l}\text { Monash Univ. } \\
\text { Australia }\end{array}$ & $\begin{array}{l}\text { Univ. of Canterbury } \\
\text { New Zealand }\end{array}$ & $\begin{array}{l}\text { EdD Univ. of West FL } \\
\text { United States }\end{array}$ \\
\hline Background & $\begin{array}{l}\text { Member of the Group of Eight } \\
\text { coalition of leading Australian } \\
\text { universities which accounts for } \\
\text { more than two thirds of all } \\
\text { Australian university research } \\
\text { activity, research output, and } \\
\text { research training. }{ }^{1} \text { Ranked } 73^{\text {rd }} \\
\text { in the world by THE }{ }^{2} \text { and } 65^{\text {th }} \\
\text { in the world by QS. }{ }^{3}\end{array}$ & $\begin{array}{l}\text { For international PhD students, } \\
\text { University of Canterbury is a } \\
\text { popular destination, ranking in } \\
\text { the top } 80 \text { of the world's } \\
\text { universities for percentage of } \\
\text { international doctoral students. } \\
\text { Ranked } 214 \text { in the world by } \\
\text { QS. }{ }^{3}\end{array}$ & $\begin{array}{l}\text { A public university that } \\
\text { conferred } 89,926 \text { degrees since } \\
\text { inception in } 1963 .{ }^{5} \text { For } 2016 \\
\text { Forbes America's Top } \\
\text { Colleges, ranked UWF \#620 } \\
\text { and \#234 in public colleges. }\end{array}$ \\
\hline $\begin{array}{l}\text { Number of } \\
\text { Campuses }\end{array}$ & $\begin{array}{l}\text { Ten. In addition to campuses in } \\
\text { Australia, Monash has } \\
\text { campuses in China, India, Italy } \\
\text { South Africa, and Malaysia. }{ }^{1}\end{array}$ & $\begin{array}{l}\text { One main campus; three small } \\
\text { campuses, four teaching centres }\end{array}$ & $\begin{array}{l}\text { One main campus; one } \\
\text { additional campus and two } \\
\text { additional offices. }\end{array}$ \\
\hline $\begin{array}{l}\text { Total Number of } \\
\text { Students }\end{array}$ & $73,016^{1}$ & $14,840^{4}$ & $12,798^{5}$ \\
\hline $\begin{array}{c}\% \text { of Females to } \\
\text { Males }\end{array}$ & $56 \% / 44 \%{ }^{1}$ & $51 \% / 49 \%{ }^{2}$ & $58 \% / 41 \% 5$ \\
\hline $\begin{array}{c}\% \text { of International } \\
\text { Students }\end{array}$ & $39 \%{ }^{1}$ & $8 \%{ }^{4}$ & $\begin{array}{l}3 \% \text { on } \mathrm{F}-1 \text { (student) or } \mathrm{J}-1 \\
\text { (exchange) visas. Non-citizen, } \\
\text { permanent residents or pending } \\
\text { an immigrant status about } 5 \% 7\end{array}$ \\
\hline $\begin{array}{l}\text { Percentage of Full- } \\
\text { time to Part-time } \\
\text { Students }\end{array}$ & $84 \% / 16 \%{ }^{1}$ & $80 \% / 20 \%{ }^{4}$ & $60 \% / 40 \%{ }^{5}$ \\
\hline $\begin{array}{l}\text { Doctoral Students } \\
\text { Enrolled }\end{array}$ & $4,444^{1}$ & $754 \mathrm{PhD}$ students in $2015^{4}$ & $\begin{array}{l}165 \text { with average of } 48 \text { doctoral } \\
\text { students admitted per year }\end{array}$ \\
\hline $\begin{array}{c}\text { Education } \\
\text { Doctoral Students }\end{array}$ & 243 in $2014^{1}$ & $\begin{array}{l}\text { NOTE TO EDITOR: This is } \\
\text { forthcoming. }\end{array}$ & $165^{6}$ \\
\hline $\begin{array}{l}\text { Doctoral Degree } \\
\text { Completions }\end{array}$ & 55 in $2014^{1}$ & $\begin{array}{l}\text { NOTE TO EDITOR: This is } \\
\text { forthcoming. }\end{array}$ & $\begin{array}{c}25 \text { average per year (2009- } \\
2014)^{6}\end{array}$ \\
\hline $\begin{array}{l}{ }^{1} \text { Monash University } \\
{ }^{2} \text { Times Higher Educ } \\
{ }^{3} \text { Quacquarelli Symo } \\
{ }^{4} \text { University of Cante } \\
{ }^{5} \text { University of West } \\
{ }^{6} \text { Personal correspon } \\
{ }^{7} \text { Personal correspon }\end{array}$ & $\begin{array}{l}\text { website, planning and statistics, } 2 \\
\text { tion (THE) World University Rar } \\
\text { ds (QS) World University Rankin } \\
\text { bury website, } 2015 \\
\text { lorida website, } 2015 \\
\text { ence and reports for 2009-2014 fr } \\
\text { ence from UWF International Stu }\end{array}$ & $\begin{array}{l}\text { UWF EdD Program Office } \\
\text { nt Services Office, } 2016\end{array}$ & \\
\hline
\end{tabular}




\section{Education PhD, Monash University (MU), Australia}

The Faculty of Education at Monash University offers a $\mathrm{PhD}$ as a traditional academically-focused research degree. The program objective is to investigate a research problem formulated independently by the Higher Degree by Research student. The research is expected to make a significant contribution to the discipline. Most recently, although largely atypical at the time of writing, in addition to a traditional thesis not exceeding 80,000 words, the thesis may comprise a minimum of three peer-reviewed papers published during candidacy together with a framing literature review, and conclusion that link to form the thesis.

Primarily the program follows the traditional method of apprenticeship in research training under guidance of a main professor and a co-supervisor. The Faculty of Education also provides intensive classroom teaching via a one-week long winter school, or on occasion throughout the year for optional learning enhancement and opportunities to network with co-students and faculty members. These teaching events are of particular value early in the doctoral program when research skills must be rapidly acquired. Active engagement with professional colleagues via participation in academic conferences specific to the area of study is also encouraged. Individual supervisors within the Faculty of Education may provide opportunities for students to teach honours classes, undertake research assistant projects, grade honours theses, or conduct administrative tasks related to students' particular research areas.

\section{Pedagogy and Milestone Assessments}

Several milestone assessments must be met throughout the duration of the program. Initially, the student must successfully pass the candidature upgrade after 12 months of study. The student has an additional three months if required to amend their work. A pass or fail is awarded and thereafter, the student is referred to as a doctoral candidate. A mid-candidature progress presentation is made to the faculty panel, ideally comprised of the original five members. Finally, a pre-submission seminar presentation is made to the faculty panel. The time between pre-submission seminar and final submission to two external examiners, during which any final amendments are made to the work, must not exceed six months. Doctoral candidates are not permitted to use the title doctor until after attending the formal commencement ceremony.

\section{Education PhD, University of Canterbury (UC), New Zealand}

The College of Education at University of Canterbury offers a $\mathrm{PhD}$ as a traditionally-focused research degree. The course of study involves extensive, sustained, original research and study in a subject of personal choice, with results being presented in a thesis that aims to contribute to the intellectual knowledge of the field. The thesis may not exceed 100,000 words and must meet recognised international standards. Higher Degree by Research students must present research outcomes thereby placing research within a broader specialization framework.

The doctoral training follows the traditional master-to-apprenticeship learning model. This model is likely to suit intelligent, self-directed students who have the potential to become independent researchers with minimal input from supervisors (Manathunga \& Goozee, 2007). A small number of supervisors offer an alternative group model of supervision that provides supportive cohort interaction. Informal peer 
connections with other Higher Degree by Research students may complement the formal supervision process by promoting scholarly development and by providing emotional and social support (Manathunga \& Goozee, 2007). In addition, University of Canterbury offers a wide range of skills workshops for students focusing on communicating research, networking, career planning, database skills, and statistical analysis. This provision allows students to extend knowledge beyond research areas and to gain specific skills and competencies.

\section{Pedagogy and Milestone Assessments}

Several milestone assessments must be met through the doctoral training. A PhD proposal and supervisory agreement form is submitted six-months post enrollment. The aim is to confirm the composition of the student's supervisory team, endorse the student's initial research proposal, and ensure that required resources are available. The $\mathrm{PhD}$ confirmation process involves submitting a written report detailing progress and identifying the next steps in the proposed research. The student also orally presents and defends thesis research with performance evaluated by the supervisory team and at least one additional person. In addition, the $\mathrm{PhD}$ student is required to submit formal progress reports every six months. This documentation includes comments from $\mathrm{PhD}$ supervisors and from the department or school postgraduate coordinator. The exact nature of the documentation required depends on the stage of $\mathrm{PhD}$ candidature.

\section{Education EdD, The University of West Florida (UWF), United States}

The UWF EdD represents a combination of two of the categories described by Huisman and Naidoo (2006): a taught doctorate and a professional doctorate. The objective is to prepare individuals who are capable of conducting and evaluating applied research and who are capable of assuming leadership roles in public education, health and human service, government agencies, and military education programs. Doctoral specializations are offered in administrative and leadership studies, curriculum and assessment studies, diversity studies, higher education, instructional design and technology, physical education, and science and social science. Enhancing accessibility to education doctorates are the curriculum and assessment studies specialization and the instructional design and technology specialization which are offered via online platforms.

Nearing the completion of coursework, students define a research topic. Students work with their doctoral chair to select a minimum of two tenure track faculty to serve on a dissertation committee. This committee, particularly the chair, guides the student through dissertation topic selection, conceptual framework determination, research design planning, data collection, data analysis, dissertation writing, and dissertation publication. Faculty committee members serve as mentors and role models for conducting scholarly research. Doctoral students are not required to teach or work on departmental research as the degree is designed to permit students to research personal areas of interest. However, students may choose to work together with committee chairs or other faculty researching topics of mutual interest. Independent study course credit may be applied. Collaborative research between students and 
UWF professors enhances socialization of the student into the research community and may lead to publication.

\section{Pedagogy and Milestone Assessments}

The UWF EdD pedagogy requires a combination of coursework, assessments, and independent research. Students complete 63-66 hours of coursework with 21 hours in professional core, 24-27 hours in a specialization, and a minimum of 18 hours of dissertation research. The professional core includes courses in quantitative research, qualitative research, mixed methods research, curriculum design, philosophical and multicultural foundations, critical issues, and psychological foundations. Within courses, objective assessments, research papers, and projects are required as formal assessments.

A milestone assessment is the preliminary examination, requiring two full days of writing responses to eight essay questions. A few weeks after this exam, students orally defend responses to the doctoral committee. The committee decides whether or not students may advance to candidacy. In some situations, a student may be required to complete additional coursework. After becoming doctoral candidates, 18 course hours are spent designing, implementing, and reporting intensive dissertation research. This process may require one to two years. The final milestone assessment is the oral dissertation defense. The title of doctor is conferred upon successful completion of the oral defense.

\section{QUALITIATIVE THEME ANALYSIS}

To align with the qualitative descriptive research method, variables were not pre-selected (sandelowski, 2000) and this permitted themes to emerge from participants' sharing of experiences. As an exploratory study representing only three education doctorate programs, enough data were not generated for the extensive coding and content analysis that is anticipated in comprehensive qualitative studies. Even so, the themes identified expose topics for broader investigations that may be used to inform enhancements to globalization-driven higher education policies. Broad themes identified were doctoral program commonalities, unprecedented growth in higher education, a globalization driven paradigm shift, and needs in contemporary doctoral education. As themes surfaced, collaborators identified related research literature to inform analyses.

\section{Doctoral Program Commonalities}

By comparing experiences in the two education $\mathrm{PhD}$ programs and the EdD program, commonalities emerged as a noteworthy theme. Each program has clearly documented entry level requirements and assessment protocols that ensure the development of similar research and administrative skills. Though dependent upon individual potential, motivation, choice of research topic, and expectations of supervisors, the REDGs acquired valuable transferable skills for use in academic and business settings. Even with various pedagogies and varying degrees of structure, each of the doctoral programs permitted REDGs to concentrate research efforts in areas of personal interest. All three REDGs independently chose research topics, questions, and designs. Indisputably, researching topics of personal interest helped sustain REDGs' momentum throughout their arduous dissertation journeys. 
Whether in the education PhD programs or the EdD program, REDGs cultivated competencies for success in research and publishing. Each of the three REDGs learned to define research problems, formulate research questions, source and quickly comprehend large volumes of information, design surveys, identify appropriate data analysis methods, conduct data analysis, and interpret research. In addition, they each developed the ability to form and defend independent conclusions and present these concepts in numerous formats including written reports of various lengths ranging from a brief abstract summary to a published research paper. All three REDGs became published journal and book chapter authors during and shortly after completing their doctoral programs. In addition, each honed communication, presentation, teaching, and networking skills by presenting research at national and international conferences.

The education doctorate programs compared enabled REDGs to develop transferable project management skills. Development of transferable skills is a critical education outcome in the era of globalization (Huisman \& Naidoo, 2006; New Zealand Ministry of Education, 2014; United States Department of Education, 2014). Taking theses and dissertation research from research design, to execution, to writing, to defense contributed to competency in project organization, task identification and prioritization, timeline formulation, problem anticipation, and project execution. REDGs become adept in exercising flexibility as circumstances often changed over their multi-year dissertation endeavours. In addition, by presenting research to faculty in oral defense settings, REDGs demonstrated the ability to appropriately respond to either positive or negative feedback, which is a transferable leadership skill.

Teamwork and collaboration skills are valued competencies in the globalization era (Salmi, 2000; United States Department of Education, 2014). REDGs honed these skills through professional relationships with supervisors and through social groups, team projects, and co-authorship of articles. Furthermore, strong international components provided opportunities to form learning partnership networks with researchers from diverse cultural backgrounds. Higher education scholars stress the importance of developing cross-cultural sensitivities pertinent to effective collaboration in international teams for solving societal problems in multinational settings (Chun \& Evans, 2016; Nerad, 2012). The research partnership developed for this study offers an example of how knowledge may be increased through cross-cultural connections.

Another commonality was similar post-doctoral outcomes for the three REDGs. By degree completion, graduates were subject experts in chosen fields with unique, in-depth, topic-specific knowledge. REDG-AU and REDG-NZ obtained research positions at internationally top-ranked universities. REDG-US enhanced her established counseling practice with the addition of consulting and the development of behavioural health technologies and training. All three REDGs indicated the doctoral experience improved confidence and motivation, enhanced their careers, and enhanced their reputations as scholars and professionals. 


\section{Unprecedented Growth in Higher Education}

Since bachelor's degrees and master's degrees are required for entry into education doctoral programs, the collaborators agreed it was useful to understand tertiary education enrollment trends. Harris (2013) traces the historical transition from elite to mass higher education in the United States and unprecedented growth in enrollments. Offerman (2011) traces similar growth in number of doctorate degrees awarded and number of institutions offering doctoral programs in the U.S. since 1900. Australia, New Zealand, and the United States are clearly experiencing extraordinary growth in tertiary enrollment (Brailsford, 2010; Edwards \& Radloff, 2013; Harris, 2013; Kena et al., 2014; New Zealand Education, 2015). In the United States, undergraduate enrollment increased by 48 percent from 12.0 million students in 1990 to 17.7 million students in 2012 and by 2023 undergraduate enrollment is projected to increase to 20.2 million (Kena et al., 2014). Countries are competing for talent, not only to provide experts to meet growing economic challenges, to improve teaching, and to improve connections to the wider world, but also to increase revenue. For example, a tertiary education strategic plan for 2014-2019 by New Zealand Ministry of Education and Ministry of Business, Innovation and Employment (2014) indicates the economic contribution from international education was valued at $\$ 2.59$ billion and was the $5^{\text {th }}$ largest export industry for the country.

Worldwide, the number of students enrolled in higher education is forecast to more than double to 262 million by 2025, with the bulk of the growth to be in the developing world (Maslen, 2012). An OECD report (2012) projects an average of 47 percent of today's young women and 32 percent of today's young men in OECD countries will complete tertiary-type education. According to a National Science Foundation ([NSF], 2014) report, 54,070 doctorate degrees were awarded by US institutions and although punctuated by brief periods of slow growth and decline, the number of doctorates awarded shows a strong upward trend over time. The OECD indicates that doctoral program graduation rates have doubled over the past 15 years, as have numbers of new universities. Mirroring the reports regarding growth in number of doctorates awarded is growth in conference attendance at Quality in Postgraduate Research (QPR) conference, the world's longest-standing conference regarding doctoral education (McCulloch \& Picard, 2015).

\section{Changing Demographics}

With such steady increases in number of doctorates awarded, it is vital to take a closer look at related changes and recipients of these advanced degrees. Schildkraut and Stafford (2015) relay how the changing demographic spurred significant changes in program delivery and led to the rise of cohort programs designed to maximize peer learning. Regarding growth, Thelin (2007) offers a historical perspective and demonstrates how enrollment growth has not been synonymous with equal access to higher education. Thelin indicates access to higher education has often been thwarted by exclusion, discrimination, legal segregation, high tuition, and lack of information. It was not until the Brown v. Board of Education decision banning segregation in education and the 1964 Civil Rights Act that the process of desegregation in U.S. education began to occur (Harris, 2013). 
Thelin (2013) also explains how patterns of exclusion by race and ethnicity are markedly different for gender. He describes how differential sorting was used by some universities prior to 1975 to make it appear women were not being discriminated against in terms of enrollments. Thelin (2013) indicates significant gains by women in numbers and proportions of graduate students. Remarkably, against the historical backdrop of exclusion and marginalization of women, each year since 2002, women earned the majority of doctorates awarded to U.S. citizens and permanent residents (NSF, 2014). Including temporary visa holders in the data collected by NSF for 2014 , women earned $46 \%$ of all doctorates awarded in the United States. The 2014 report also indicates the number of doctorate recipients in the United States increased for both men and women every year since 2010.

Similarly, Offerman (2011) indicates that traditional doctoral students were white, male, participating full-time in a doctoral program, age 22 to 30, single, and childless. Offerman suggests that such a broad change has occurred in demographics of doctoral students that a shift in terminology from nontraditional doctoral student to contemporary doctoral student is essential. Offerman indicates that contemporary doctoral students are increasingly racially diverse, increasingly female, participating parttime in a doctoral program, more than 30 years old, with children and/or dependent parents. Chun and Evans (2016) cite various reports indicating continued growth in the percentage of minority students in the United States and predict the emergence of a minority majority American nation by 2042.

According to the NSF (2014) report, the steady growth in number of doctorates awarded per year in the United States is not only to U.S. citizens and permanent residents. There is steady growth over time in doctorates awarded to temporary visa holders in the United States. In the ten-year period 2004 to 2014, the top three foreign citizens who earned doctorates in the United States were from China $(46,121$ doctorates awarded), India $(21,444)$, and South Korea $(15,717)$. Clearly, internationalization and increasing diversity of students in higher education stresses the urgency in preparing students with the knowledge and expertise required to work in a global, multicultural society (Chun \& Evans, 2016).

\section{Globalization-Driven Doctoral Training Paradigm Shift}

The comparison of the three education doctoral programs sparked interest in understanding reasons for the varied and evolving approaches to training. A globalization-driven paradigm shift has influenced a shift from polarity between academic doctorates and professional doctorates to a spectrum of contemporary doctoral approaches (Scott, Brown, Lunt, \& Thorne, 2004; Wellington \& Sikes, 2006). In addition, universities are increasingly identified as critical members of a global market that serves consumers of training and research products (Altbach, 2004; Jamieson \& Naidoo, 2007; Kehm, 2007) and scholars note that such globalization forces are changing the nature and purpose of higher education worldwide (Jamieson \& Naidoo, 2007; Nerad, 2004; Nerad, 2012; Scott, 2006). A manifestation is an opening message in the U.S. Department of Education Strategic Plan for Fiscal Year 2014-2018 (2014) indicating the importance of education in today's global economy and the need for students to develop academic and technical skills that encompass critical thinking, collaboration, and communication. 
Some scholars express caution about moving too far away from striving to develop critical-thinking skills to the functionalist, skills-led perspective that emphasizes business, communication, and leadership. In doctoral education, Powell and Green (2007) advocate for maintaining a balance between skills-based and knowledge-based approaches to doctoral education. Bloch, Graversen, and Pedersen (2015) support this assertion suggesting that the structural composition of the economy does not seem to support transitions between sectors given various work tasks in various employment sectors. Bloch and colleagues argue that it is difficult to transfer competencies from academia to the business sector as skills obtained in one sector are often not valued equally in another, which may explain the limited transitions between sectors noted by Mangematin (2000).

\section{Positive Impact of the Digital Transformation}

Salmi (2000) indicated the converging challenges of economic globalization, digital transformation, and the knowledge economy would bear heavily on the roles and functions of higher education. Educational technology has indeed revolutionized higher education (Harris, 2013; Havard, East, Prayaga, \& Whiteside, 2016). Collaborators agree with Fuller, Risner, Lowder, Hart, and Bachenheimer (2014) who purport that the digital transformation has enhanced education. Each of the three programs compared offer easy access to online libraries, remote access to various software programs, and access to cuttingedge technologies that permit reaching beyond physical locations. The collaborators in this research project for example, worked remotely from Australia, New Zealand, and the United States using a private Facebook group, email, live video conferencing, online scholarly search engines, text messaging, and file sharing through Google Drive and Evernote.

Along these lines, Haggans (2015) indicated the metaphorical walls of higher education are crumbling and to avoid a similar fate, Haggans stressed the need for prioritizing problem-solving regarding the literal walls and campuses. Although universities are in flux, Bonvillian and Singer (2013) describe universities as innovation systems that are critical for societal growth for which there is no substitute. Higher education professionals predict the continued existence of traditional institutions, yet also predict that technology will continue to have a major impact on higher education (Franklin, 2015).

\section{The Evolution of Online Doctoral Programs}

Contemporary doctoral programs are increasing access to doctoral education through the flexibility inherent in online courses and online support services. Offerman indicates the evolving student profile has driven dramatic changes in doctoral programs and faculty relationships with students. As a case in point, Ntiri (2001) describes how technology and distance learning enhances access to higher education for women who may be juggling multiple responsibilities. Although improving access to higher education often meets resistance from existing institutions and the professoriate (Annand, 2015), Bonvillian and Singer (2013) suggest that the future of universities may depend upon blending the strengths of online education with the strengths of face-to-face education.

Affordable video conferencing technologies and course management systems have made electronic learning and distance supervision possible. Distance education or online learning, a challenge to the traditional lecture-based face-to-face course format, has evolved as a sustainable approach to higher 
education (Annand, 2015; Kena et al., 2014) and according to Fuller et al. (2014), online doctoral education has become more prevalent. The education doctorate at The University of West Florida provides an example of the online doctorate evolution as most of its required courses are offered in an online format. The online strategy makes an education doctorate accessible to people who do not live within driving distance of the campus. Online courses in UWF's structured approach to the education doctorate require participation in e-learning discussion forums and development of group projects through Web 2.0 collaboration tools. Unquestionably, incorporating these methods into pedagogy enhances development of the teamwork and collaboration skills that are highly valued in today's global market.

Although technology permits remote access to doctoral education, quality online education is a concern that emerged. Digital immigrant professors (Prensky, 2001) may be expert scholars but may lack online course delivery knowledge and skills. In order to successfully execute an online course and contribute to learning, being experts in a particular field of knowledge is insufficient: Instructors must be equipped with knowledge of online course delivery theory, best practices in distance learning, and models such as the Community of Inquiry for online learning (Garrison, Anderson, \& Archer, 2010).

Garrison and Arbaugh (2007) highlight an explosion of empirical research regarding online learning effectiveness. They note the advancement of the Community of Inquiry model with its emphasis on social, cognitive, and teaching presence as an effective tool for conceptualizing the online learning process. Havard et al. (2016) developed a contemporary framework based on the Community of Inquiry model useful for connecting pedagogy with educational technology, Adaptable Learning Theory Framework for Technology Enhanced Learning. Doctorate holders who secure faculty positions are likely to teach online courses. Therefore, in order to be successful in achieving educational outcomes, it is critical for doctorate holders to develop expertise in online course theory and delivery.

\section{Needs in Contemporary Doctoral Education}

\section{Need to Advance Accessibility to Doctoral Education}

In a knowledge economy context, knowledge is viewed as a critical national resource and this perspective is reflected in higher education policies that aim to enhance contributions of doctoral programs to national economic growth and development (McCulloch \& Picard, 2015; Nerad, 2012; Pedersen, 2014). This logically relates to the issue of access to doctoral education. Healey and Gunby (2012) indicate accessibility suggests low barriers to university entry in terms of affordability and non-discriminatory entrance requirements.

All three of the REDGs experienced negligible accessibility issues and indicated globalization and the digital transformation enhanced their access to doctoral education. All three indicated structured, efficient application processes, clearly presented program requirements, and user-friendly online access to library resources. In addition, all three indicated positive experiences with accessing and collaborating with faculty mentors, whether through video chat, email, or face-to-face. The successes of the three 
REDGs as contemporary or non-traditional students indicates how access to doctoral education has evolved and improved in view of globalization and the digital transformation.

Access to doctoral education, however, needs to be continually monitored and improved. Although barriers to higher education have been reduced by globalization with the three females in the study reporting negligible accessibility issues, barriers to doctoral education continue to exist for women and other marginalized groups. Accessibility is unquestionably a challenge for people who are marginalized by disabilities, gender, race, ethnicity, economic barriers, lack of internet access, or cross-cultural communication barriers (Healy \& Gunby, 2012; Huisman \& Naidoo, 2006; Kirshin, 2014). Burke (2013) cautions against surface-level multiculturalism that contributes to ignoring privilege and racism as explanatory factors of disparities. One of the principles of the CPED discussed by Perry (2016) is that the professional doctorate in education must be framed around questions of equity, ethics, and social justice to solve complex problems of practice. As more educational leaders are trained according to this principle it is likely that access to higher education will continue to become more equitable.

Thelin $(2007,2013)$ also indicates that increasing enrollment does not imply quality of education or parallel increases in completion rates. Thelin explains that while post 1960's master plans were good at enrolling students, the plans lacked form and process guidance for inducing sound educational experiences. According to Thelin, reforms to increase enrollments, to enhance social justice, and to promote equal access to higher education inadvertently place pressures on the structures and systems; this makes it difficult for universities to maintain efficiency and high graduation rates.

\section{Need to Increase Quantity of Doctorate Holders and Completion Rates}

Past forces such as the industrialization era and the post World War II economic era have certainly shaped directions in higher education (Thelin, 2007, 2013). Likewise, the current era of globalization is transforming higher education and influencing trends such as growth in doctoral completion rates. According to Kena et al., 2014, the number of doctorate degrees awarded in the United States increased by 42 percent from 2002 to 2012. Although the number of doctorate holders produced each year has increased in OECD countries and many other countries (Bloch, Graversen, \& Pedersen, 2015; Pedersen, 2014) empirical evidence suggests a need for even more doctorate holders in order to effectively stimulate economic growth (Kehm, 2007; Nerad, 2012). Many countries have defined specific targets for increasing the number of doctorate holders (Pedersen, 2014).

The need for more doctorate holders relates to the challenge of improving doctoral degree completion rates. The OECD Innovation Strategy (2010) indicates doctorate holders are integral to global innovation systems by enriching and advancing science, technology, and innovation. OECD, therefore, supports increasing the supply of doctorate holders. Pedersen (2014) connects investment into increasing doctorate holders to broader research and development policy initiatives.

Offering a cautionary perspective, Pedersen (2014) examines key issues related to the need to increase the number of doctorate holders and notes doctoral program graduates may not be easily 
absorbed into employment. Pedersen suggests that although there appears to be valid argumentation for increasing the doctoral labor force, priorities for increasing the number of doctorate holders may not align with perceived demand. Pedersen notes the need for more research to assess the job market for doctorate holders and also explains how up-scaling the number of doctorate holders may affect the functioning of existing labor markets.

\section{Need to Improve Quality Assurance for Private For-Profit Higher Education Institutions}

While the number of U.S. private non-profit institutions and the number of public institutions decreased slightly from 2001 to 2013 , the number of private for-profit institutions nearly doubled in that same period, from 687 to 1,368 (Kena et al., 2014). The private tertiary education sector in Australia has described continuing growth (Edwards \& Radloff, 2013; Shah \& Stanford, 2013) with record growth in the international education industry. Such rapid growth in private for-profit institutions worldwide has contributed to perplexing issues related to quality assurance and standards (Shah \& Stanford, 2013).

Reflecting this challenge are recent closings of U.S. private for-profit institutions amidst concerns about organizational integrity, financial viability, and ability to serve students. Corinthian Colleges was shut down in 2015, stranding 16,000 students with student loans and no degrees (Stratford, 2015). According to the U.S. Department of Education's website, the high profile ITT Technical Institute was shut down in September 2016. The closure of the chain's 137 campuses displaced 35,000 students. The closings prompted Corporation for Public Broadcasting to air the film, A Subprime Education (Gaviria \& Smith, 2016) about the allegations of fraud and predatory behavior in the troubled for-profit college industry.

\section{Need for Quality Supervision and Alternatives to Traditional Apprenticeship Model}

Quality supervision emerged as a challenge in education doctorate training. The three REDGs in this exploratory study indicated they were effectively mentored into the academic world by supervisors. One of the REDGs noted, however, that even though supervisors were accessible and supportive, they occasionally mentioned struggles in being able to effectively support the increasing volume of doctoral candidates. As economic demands and funding changes emphasize research outputs, supervisors are under increasing pressure not only to mentor and guide numerous doctoral students, but also to publish (Taylor, 2013). Such pressures reduce the time available for supervisor-student meetings and may contribute to problematic supervision (McCallin \& Nayar, 2012). Not all doctoral students are suited to working independently. Without adequate supervision, the pressures of funding degree study and the stresses of life outside the university may lead to struggles with maintaining momentum and adhering to completion time constraints. McCallin and Nayar (2012) also point out that not all university instructors are specialized in supervision and suggest formal supervision training.

Highly skilled and qualified researchers being viewed as strategic assets drives a propensity toward a paradigm shift away from the traditional apprenticeship model of doctoral training to a more structured learning process for preparing scholars to address contemporary issues in a global market (McCulloch \& Picard, 2015; Nerad 2010, 2012). Some scholars indicate the apprenticeship model limits discussions with 
other students and faculty (Neumann, 2005) and contributes to limited development of researchers' skills (Walker et al., 2008). The coursework-based education doctorate offered by The University of West Florida and the workshops offered by Monash University and University of Canterbury reflect varying degrees of the paradigm shift away from sole reliance upon the traditional apprenticeship model of training. Perry's (2016) work in the Carnegie Project on the Education Doctorate indicates the traditional mentor-mentee relationship is no longer the norm in redesigned EdD programs. Instead, Perry indicates the faculty instructor brings research and theoretical skills to the partnership and the practitioner-student brings experience and practitioner knowledge to the partnership. Group advising, according to Perry, has become a more manageable way to work with a larger number of EdD candidates.

\section{Need for Standardization}

An increasing focus on doctorate holders' employability has led to attempts to identify a crucial set of competencies and skills that doctoral education should provide (Matas, 2012; Nerad, 2010) in order to make competence of doctorate holders transparent to potential employers (Pedersen, 2014). The next generation of doctorate holders is not only expected to contribute to knowledge through original research and to possess substantial specialization knowledge; doctorate holders are also expected to develop transferable, transitional, and cultural competencies in order to better meet the needs of the employment market (Boud \& Tennant 2006; Chun \& Evans, 2016; Matas, 2012; McCulloch \& Picard, 2015; Nerad, 2012; Nicholls, 2014; Pedersen, 2014).

Doctorate holders are expected to work in international teams and collaborate with researchers outside their own communities and countries. Therefore, the acquisition of cultural competencies is a crucial part of doctoral training (Nerad, 2012). Chun and Evans (2013) note on the other hand, that universities struggle with imparting cultural competence in part due to lack of a clear definitional framework and overlapping terminology. The authors demonstrate how a watered-down concept of international study with universities encouraging students to get to know people from other nations may actually interfere with development of cultural competence. Chun and Evans indicate that doctoral training must strive to equate cultural competence with the implications of inequality, social stratification, oppression, and privilege. Chun and Evans call for a transformative paradigm for diversity, and replacing the term cultural competence with the term diversity competence. The authors present a model for systematically and intentionally addressing diversity learning outcomes in doctoral education.

A potential benefit of doctoral education standardization is greater mobility of researchers during and after completion of the degree (Nerad, 2012). Typically, the flow of doctorate holders is from developing countries to large metropolitan academic systems. Enticed by salary packages, advantageous working conditions, and academic autonomy (Altbach and Levy, 2006), many doctorate holders avoid returning to home countries (Altbach, 2004; Nerad, 2010, 2012). This phenomenon is brain gain for receiving countries and brain drain for countries who have lost scholars (Nerad, 2010, 2012). Altbach (2004) notes that migrating scholars are likely to maintain mutually beneficial connections with home country colleagues and that scholars may return to home countries upon completing terms as visiting professors or 
other temporary research positions. Home countries may thereby benefit from doctorate holders' knowledge and experience gained abroad.

\section{Need for Additional Faculty and Solution to Contingent Academic Labor}

Unparalleled growth, mass education, and increasing access to higher education is driving an increased need for faculty. Trying to keep pace, universities are reacting by adding contingent labor i.e. non-tenuretrack faculty. Thelin's (2007) history of higher education essay noted a developing rise in hiring adjuncts, part-time instructors, clinical faculty, and grant project researchers along with a reduction in hiring tenure track professors. By 2011, 50 percent of U.S. faculty were on part-time status (Aud, Wilkinson-Flicker, Nachazel, \& Dziuba, 2013). The Condition of Education 2014 report (Kena et al., 2014) indicates a 42 percent increase of full-time faculty and a 162 percent increase of part-time faculty in degree-granting postsecondary U.S. institutions in the period 1991 to 2011. Osborne et al. (2014) indicates similar rates of part-time faculty in the United Kingdom and Canada.

Goldstene (2012) describes troubling commonalities for adjunct faculty including low pay, ineligibility for health and retirement benefits, teaching multiple courses on multiple campuses, and being given little time to prepare for teaching courses. Goldstene also points out that adjuncts are typically excluded from university governance and are anonymous entities in their departments and thereby demonstrates how this situation weakens the autonomy of all faculty and undermines academic freedom. Not only is the impact of this trend worrisome for the adjunct faculty. Thelin (2007) notes that while contingent labor and an abundance of new administration positions may bring fresh expertise and flexibility, a parallel cost is that the highly skilled, accomplished professoriate is being pushed from centre stage to the margins of higher education.

Even the term adjunct is controversial and many feel demeaned by the term (Block, 2016). In a provocative essay, Block indicates much disagreement over use of the adjunct label as well as other terms such as instructor, professor emerita, and part-time faculty. Some advocate for not distinguishing between adjunct and other faculty, yet others express concern that failing to identify adjunct faculty as such, could create a false assumption that all is well when it is not. Block notes the only universal opinion is that greater security and respect are warranted regarding educators who teach part-time.

In approaching solutions, Kezar and Sam (2010) explore the intersection of ideological, practical, and empirical tensions that arise from the trend of involving non-tenure-track faculty. Kezar and Sam call for more open debate regarding ideological tensions and increased brainstorming regarding practical tensions. The authors also demonstrate how previous research has contributed to tensions between tenured and non-tenured faculty by not holding working conditions constant and by not distinguishing between part-time and full-time non-tenure-track faculty. Kezar and Sam call for further research to clarify these empirical tensions.

Additionally, Kezar and Sam call for intentionality in incorporating non-tenure-track faculty to staff higher education as opposed to implementing reactionary approaches. Some intentional alternatives are 
offered by Kezar and Sam such as converting non-tenure-track faculty to tenure-eligible tracks over time as it becomes financially feasible, setting tenure or faculty appointment quotas, and broadening tenure to include a balance of teaching, research, and service. Other alternatives explored by Kezar and Sam are developing new appointment types altogether such as long-term contracts, professionalizing non-tenured faculty by offering multiyear contracts with greater equity in pay and benefits, intentionally creating hiring and socialization processes, and creating hybrid institutions where faculty can opt for tenure or multiterm contracts. Kezar and Sam make a strong case for institutions to advance the message that nontenure-track faculty are valued and respected and offer a detailed plan for professionalizing non-tenuretrack faculty.

\section{FUTURE RESEARCH DIRECTIONS AND POLICY IMPLICATIONS}

From this comparative review of education doctorates in three countries, a number of avenues for further research are suggested. First, with this being an exploratory study, the sample size was limited to three recent doctoral graduates from three universities. Multiple institutions across countries should be surveyed to provide a comprehensive understanding of the impact of globalization on doctoral education. Research is also needed to determine if there are significant differences in career outcomes based upon the evolving and various approaches to doctoral education. Additionally, rapid growth in higher education enrollments necessitates ongoing research regarding quality and oversight of doctoral programs.

Qualitative and mixed method research will be particularly useful in studying increasing enrollments of women and minorities in doctoral education. A goal of such studies should be to determine the extent to which the unique needs of marginalized individuals are accommodated throughout doctoral journeys. Studies are also needed to better understand access to postdoctoral research positions and careers for contemporary doctorate achievers who may also be members of marginalized groups. Along these lines, studies are needed to determine the societal status of doctorate holders who may also be members of marginalized groups, i.e., determining to what degree contemporary doctorate holders are esteemed compared to the esteem and privilege granted to the typical traditional doctorate holders of the past. Research is needed to determine outcomes of the concentrated effort to impart an ethics, equity, and social justice framework in doctoral programs. Pretest-posttest designs comparing pre-doctoral attitudes and knowledge with post-doctoral attitudes and knowledge regarding ethics, equity, and social justice will be useful in evaluating progress and identification of gaps.

Regarding the digital transformation, rigorous research is needed to determine how to further exploit technologies to increase access to doctoral education and to quality supervision. As technologies are employed in the practice of remote group supervision of doctoral candidates for example, studies are needed to evaluate the efficacy of the methods. Successful implementation of group supervision has the potential to increase access to mentorship to increasing numbers of doctoral students without overburdening the mentors. More studies are needed regarding successes, challenges, and even failures of various educational technologies specifically used in doctoral education. 
Policies are needed to encourage the professoriate to learn and apply instructional design and distance learning theory, frameworks for technology-enhanced learning, and best practices in online course design to the delivery of doctoral-level online courses. As professors become skilled in the delivery of online courses, reputations of online doctoral level course delivery will be enhanced, and this in turn has the potential to increase access to doctoral education. Along these lines, further efforts are also needed to refine and develop instruments to assess faculty mentoring and its effectiveness. Outcomes of such research will provide evidence-based foundations for developing effective faculty training regarding transitioning doctoral courses and supervision to online formats.

Additional research is warranted regarding the impact of the paradigm-shift toward standardization of doctoral programs and related reforms. In order to permit longitudinal impact assessments of reforms, further studies will require multilevel, multidisciplinary, and methodologically-diverse approaches. Creating channels in the research process to include input from industry partners is a vital step in ensuring that doctoral program graduates' competencies are appropriate for the workplace. A need also exists for ongoing, timely, global higher education data regarding time to completion and completion rates (Brailsford, 2010). Finally, a critical need exists for research that will guide development of solutions to the burgeoning problem of contingent academic labor and related terminology.

\section{CONCLUSION}

Useful insight into education doctoral programs through the lens of globalization emerged through this collaboration of researchers affiliated with contemporary education doctoral programs in three countries. The broad themes identified though this exploratory qualitative interpretive study were doctoral program commonalities, unprecedented growth in higher education, a globalization-driven paradigm shift, and contemporary needs in doctoral education. Findings offer tentative evidence that although approaches to the education doctorate vary in form, the research, management, collaboration, and problem-solving skills developed are similar and valuable for helping countries address critical globalization-driven needs. The intersection of globalization, exponential knowledge growth, and the digital transformation has clearly contributed to an increased demand for doctorate holders with skills for developing solutions to the extraordinary growth in higher education, production sustainability, and economic viability.

Access to quality doctoral education is of utmost importance as researchers are increasingly viewed as important strategic assets and commodities (McCulloch \& Picard, 2015; Nerad, 2012). Doctoral program planners need to consider the paradigm shift away from traditional apprenticeship supervision pedagogy to evidence-based structured and standardized approaches. This is needed not only to prepare doctorate holders to be knowledge experts in a specialization but also to ensure the development of cultural competencies and business, leadership, and communication skills (McCulloch \& Picard, 2015). It will also enhance mobility of doctorate holders. For sustainability and enhancing accessibility, doctoral programs need to carefully plan the integration of online education, ensuring faculty are trained in distance education theory and best practices. This study further points to the need for research, evidence- 
based problem-solving, and policy enhancement regarding the growth in doctoral program enrollments and the consequential need for more faculty.

As a final point, Thelin (2013) suggests the solution to meeting contemporary challenges in higher education is not increasing funding because that promotes business as usual and lack of efficiency. Thelin calls for a clear, fresh focus on the essential questions of educational purpose and renegotiation of charters and societal compacts. Thelin's call reflects the thread of intentionality identified in the contemporary doctoral education literature (Chun \& Evans, 2016; Kezar \& Sam, 2010; Pedersen, 2014; Perry, 2016). In order to enhance doctoral education and to enhance accessibility to these programs, changes must be research based, practice-informed, and clearly intentional as opposed to implementing temporary reactionary measures. Moving forward with research-based, practice-informed, and intentional reforms will lead to increasing the supply of scholarly practitioners (Perry, 2016) needed to help solve globalization-driven challenges. 


\section{REFERENCES}

Altbach, P., \& Levy, D. (2006). Private higher education: A global revolution. Rotterdam, The Netherlands: Sense Publishers.

Annand, D. (2015). Developing a sustainable financial model in higher education for open educational resources. International Review of Research in Open and Distance Learning, 16(5), 1-15.

http://www.irrodl.org/index.php/irrodl

Aud, S., Wilkinson-Flicker, S., Nachazel, T., \& Dziuba, A. (2013). The condition of education 2013. Washington, DC: U.S. Department of Education, National Center for Education Statistics.

Berg, B. L., \& Lune, H. (2012). Qualitative research methods for the social sciences, 8th edition. [Kindle Edition]. http://www.amazon.com/Kindle-eBooks/b?ie=UTF8\&node=154606011

Blackstone, A. (2012). Principles of sociological inquiry: Qualitative and quantitative methods. ISBN: 978-1-4533288-9-7. Washington, DC: Flat World Knowledge. http://catalog.flatworldknowledge.com/bookhub/reader/3585?e=blackstone_1.0-ch02_s01

Bloch, C., Graversen, E. K., \& Pedersen, H. S. (2015). Researcher mobility and sector career choices among doctorate holders. Research Evaluation, 24(1), 171-180. http://dx.doi.org/10.1093/reseval/rvv004

Block, M. S. (2016). Is “adjunct” a bad word? HigherEdJobs, September 8, 2016. https://www.higheredjobs.com/Articles/articleDisplay.cfm?ID=1038\&utm_source=09_14_2016\&utm_m edium=email\&utm_campaign=InsiderUpdate

Bonvillian, W. B., \& Singer, S. R. (2013). The online challenge to higher education. Issues in Science and Technology, 29(4), 23-30.

Boud, D., \& Tennant, M. (2006). Putting doctoral education to work: Challenges to academic practice. Higher Education Research and Development, 25(3), 293-306.

http://dx.doi.org/10.1080/07294360600793093

Brailsford, I. (2010). Doctoral completion: Can history teach us anything? New Zealand Journal of Educational Studies, 45(2), 61-74.

Burke, M. A. (2013). Colorblindness vs. race-consciousness: An American ambivalence [Special Feature]. The Society Pages, W. W. Norton and Company.

https://thesocietypages.org/specials/colorblindness-vs-race-consciousness/

Card, K., Chambers, C. R., Freeman, Jr., S. (2016). Is there a core curriculum across higher education doctoral programs? International Journal of Doctoral Studies 11, 127-146.

http://www.informingscience.org/Journals/IJDS/Overview 
Carter, D. S. G. (1994). A curriculum model for administrator preparation and continuing professional development. Journal of Educational Administration, 32(2), 21.

http://dx.doi.org/10.1108/09578239410062905

Chun, E., \& Evans, A. (2016). Rethinking cultural competence in higher education: An ecological framework for student development. ASHE Higher Education Report, 42(4), 7-162.

doi:10.1002/aehe.20102

Clifford, G. J., \& Guthrie, J. W. (1988). Ed school: A brief for professional education. Chicago:

University of Chicago Press.

Etikan, I., Abubakar, M., Alkassim, S. (2016). Comparison of convenience sampling and purposive sampling. American Journal of Theoretical and Applied Statistics 5(1), 1-4.

doi:10.11648/j.ajtas.20160501.11

Flores, E. (2011). Becoming a researcher: A qualitative study of the apprenticeship model in doctoral education. PhD dissertation, Seattle, Washington: University of Washington.

Franklin, D. S. (2015). 'Will the internet ever replace colleges and universities as we know it today?' An internet discussion about the future of higher education. Procedia-Social and Behavioral Sciences, 176, 738-744.

Fuller, J., Risner, M., Lowder, L., Hart, M., \& Bachenheimer, B. (2014). Graduates' reflections on an online doctorate in educational technology. Techtrends: Linking Research \& Practice to Improve Learning, 58(4), 73-80.

Garrison, D. R., Anderson, T., \& Archer, W. (2010). The first decade of the community of inquiry framework: A retrospective. The Internet and Higher Education, 13(1), 5-9.

Garrison, D. R., \& Arbaugh, J. B. (2007). Researching the community of inquiry framework: Review, issues, and future directions. Internet and Higher Education, 10(3), 157-172.

Gaviria, M. (Producer), \& Smith, M. (Correspondent). (2016). Frontline, Spotlight in Education: A Subprime Education. [Film]. United States: Corporation for Public Broadcasting, PBS.

http://www.pbs.org/wgbh/frontline/film/a-subprimeeducation/?utm_source $=$ email\&utm_medium $=$ social\&utm_campaign $=$ share_button

Golde, C. M., \& Dore, T. M. (2001). At cross purposes: What the experiences of doctoral students reveal about doctoral education, a report for the Pew Charitable Trusts. Philadelphia, PN: Pew Charitable Trusts.

Goldstene, C. (2012). The politics of contingent academic labor. The NEA Higher Education Journal, Thought and Action, Fall 2012, 7-15. 
Hackman, D. G. (2016). Considerations of administrative licensure, provider type, and leadership quality: Recommendations for research, policy, and practice. Journal of Research on Leadership Education, 11(1), 43-67. doi: 10.1177/1942775116641662

Haggans, M. (2015). The future of the American campus. On the Horizon, 3(1), 25-32. http://dx.doi.org/10.1108/OTH-11-2014-0038

Harris, M. S. (Ed.). (2013). Understanding institutional diversity in American Education [Special issue]. ASHE Higher Education Report, 39(3), 1-121. doi:10.1002/aehe.20009

Havard, B., East, M. L., Prayaga, L., \& Whiteside, A. (2016). Adaptable learning theory framework for technology enhanced learning. In E. Railean, G. Walker, L. Jackson, and A. Elci, (Eds.), Handbook of applied learning theory and design in modern education (Chapter 31, pp. 646-668). Hershey, PA: IGI Global. http://dx.doi.org/10.4018/978-1-4666-9634-1

Healey, N., \& Gunby. (2012). The impact of recent government tertiary education policies on access to higher education in New Zealand. Journal of Educational Leadership, Policy and Practice, 27(1), 29-45. http://nzeals.org.nz/jelpp.htm

Huisman, J., \& Naidoo, R. (2006). The professional doctorate: From Anglo-Saxon to European challenges. Journal of the Programme on Institutional Management in Higher Education, Higher Education Management and Policy, 18(2), 1-132.

Jamieson, I. \& Naidoo, R. (2007). University positioning and changing patterns of doctoral study: the case of the University of Bath. European Journal of Education, (42)3, 363-373.

Kehm, B. M. (2007). Quo vadis doctoral education? New European approaches in the context of global changes. European Journal of Education, 42(3), 307-319.

Kena, G., Aud, S., Johnson, F., Wang, X., Zhang, J., Rathbun, A., Wilkinson-Flicker, S., \& Kristapovich, P. (2014). The condition of education 2014, NCES 2014-083. Washington, DC: U.S. Department of Education, National Center for Education Statistics.

Kezar, A., \& Sam, C. (2010). Understanding the new majority of non-tenure-track faculty in higher education-Demographics, experiences, and plans of action. ASHE Higher Education Report, 36(4), 1133.

Kirshin, I. A. (2014). Modeling the long-term trend of accumulation of knowledge. Life Science Journal, $11(6), 482-486$.

Kot, F. C., \& Hendel, D. D. (2012). Emergence and growth of professional Doctorates in the United States, United Kingdom, Canada and Australia: A comparative analysis. Studies in Higher Education, 37(3), 345-364. http://dx.doi.org/10.1080/03075079.2010.516356 
Manathunga, C., \& Goozée, J. (2007). Challenging the dual assumption of the 'always/already' autonomous student and effective supervisor. Teaching in Higher Education, 12(3), 309-322. http://dx.doi.org/10.1080/13562510701278658

Mangematin, V. (2000). PhD job market: Professional trajectories and incentives during the PhD. Research Policy, 29(6), 741-756. http://dx.doi.org/10.1016/s0048-7333(99)00047-5

Maslen, G. (2012, February 19). Worldwide student numbers forecast to double by 2025. University World News, 209. http://www.universityworldnews.com/article.php?story=20120216105739999

Matas, C. P. (2012). Doctoral education and skills development: An international perspective. REDU: Revista de Docencia Universitaria, 10(2), 63-191

McCallin, A., \& Nayar, S. (2012). Postgraduate research supervision: A critical review of current practice. Teaching in Higher Education, 17(1), 63-74. http://dx.doi.org/10.1080/13562517.2011.590

McCulloch, A., \& Picard, M. Y. (2015). 'PhD, meet QPR': The quality in postgraduate research conference and the development of doctoral education. International Journal for Researcher Development, 6(1), 2-8. http://dx.doi.org/10.1108/IJRD-03-2015-0008

Monash University. (2016). University planning and statistics, summary reports. http://www.monash.edu/ups/statistics/summary-reports

National Policy Board for Educational Administration. (1989). Improving the preparation of school administrators: An agenda for reform. Charlottesville, VA: National Policy Board for Educational Administration.

National Policy Board for Educational Administration. (2015). Professional Standards for Educational Leaders 2015. Reston, VA: National Policy Board for Educational Administration.

National Postdoctoral Association. (2015). NPA core competencies: The NPA postdoctoral core competencies toolkit, 2007-2009. http://www.nationalpostdoc.org/competencies

National Science Foundation (2014). Doctorate Recipients from U.S. Universities: 2014. https://www.nsf.gov/statistics/2016/nsf16300/digest/index.cfm

Nerad, M. (2004). The PhD in the U.S.: Criticisms, facts, and remedies. Higher Education Policy, 17(2), 183-199. http://dx.doi.org/10.1057/palgrave.hep.8300050

Nerad, M. (2010). Globalization and the internationalization of graduate education: A macro and micro view. Canadian Journal of Higher Education, 40(1), 1-12.

Nerad, M. (2012). Conceptual approaches to doctoral education: A community of practice. ALTERnation, $19(2), 57-72$. 
Neumann, R. (2005). Doctoral differences: Professional doctorates and PhDs compared. Journal of Higher Education and Policy Management, 27(2), 173-188.

http://dx.doi.org/10.1080/13600800500120027

New Zealand Education, ThinkNew. (2015). New Zealand International Education Snapshot: January to August 2014. http://enz.govt.nz/markets-research/general-research/new-zealand-international-educationsnapshot-january-to-august-2014

New Zealand Ministry of Education, Ministry of Business, Innovation and Employment. (2014). Tertiary Education Strategy 2014-2019. http://www.education.govt.nz/further-education/policies-andstrategies/tertiary-education-strategy/

Nicholls, G. (2014). Professional development in higher education: New dimensions and directions. New York, N.Y: Routledge.

Ntiri, D. W. (2001). Access to higher education for non-traditional students and minorities in a technology-focused society. Urban Education. 36(1), 129-144. doi:10.1177/0042085901361007

Offerman, M. (2011). Profile of the Nontraditional doctoral degree student. New Directions for Adult and Continuing Education, 129, 21-30. doi:10.1002/ace.397

Organization for Economic Cooperation and Development. (2010). The OECD innovation strategy: Getting a head start on tomorrow. Paris, France: OECD Publishing.

Organization for Economic Cooperation and Development. (2012). Education at a glance 2012: OECD indicators. Paris, France: OECD Publishing.

Osborne, B. J., Carpenter, S., Burnett, M., Rolheiser, C., \& Korpan, C. (2014). Introduction from the special issue editors: Preparing graduate students for a changing world of work. The Canadian Journal of Higher Education, 44(3), I-IX.

Pedersen, H. K. (2014). New doctoral graduates in the knowledge economy: Trends and key issues. Journal of Higher Education Policy and Management. 36(6), 632-645.

doi:dx.doi.org/10.1080/1360080X.2014.957891

Perry, J. A. (2015). The Carnegie project on the education doctorate. Change: The Magazine of Higher Learning, 47(3), 56-61. doi:10.1080/00091383.2015.1040712

Plans of Action and Promising Policies. (2010). ASHE Higher Education Report, 36(4), 77-106.

Prensky, M. (2001). Digital natives, digital immigrants: Part 1. On the Horizon, 9(5), 1-6. http://dx.doi.org/10.1108/10748120110424816 
Powell, S., \& Green, H. (2007). The doctorate worldwide. Berkshire, U.K.: Open University Press Maidenhead.

Quacquarelli Symonds Limited. (2014). QS world university rankings.

http://www.topuniversities.com/qs-world-university-rankings

Salmi, J. (2000). Tertiary education in the twenty-first century: Challenges and opportunities. World Bank, Washington DC. http://documents.worldbank.org/curated/en/2000/06/5840479/tertiary-educationtwenty-first-century-challenges-opportunities-tertiary-education-twenty-first-century-challengesopportunities

Sandelowski, M. (2000). Focus on research methods: Whatever happened to qualitative description? Research in Nursing and Health, 23, 334-340.

Schildkraut, J. \& Stafford, M. C. (2015). Researching professionals or professional researchers? A comparison of professional doctorate and $\mathrm{PhD}$ programs in criminology and criminal justice. American Journal of Criminal Justice, 40, 183-198. doi:10.1007/s12103-014-9240-z

Scott, D., Brown, A., Lunt, I., \& Thorne, L. (2004). Professional doctorates: Integrating professional and academic knowledge. Maidenhead, United Kingdom: Society for Research into Higher Education and Open University Press.

Scott, J. C. (2006). The mission of the university: Medieval to postmodern transformations. The Journal of Higher Education, 77(1), 1-39. http://dx.doi.org/10.1353/jhe.2006.0007

Shah, M., \& Stanford, S. (2013). Quality and regulation of Australian tertiary education: Searching for a sustainable quality assurance framework. The ACPET Journal for Private Higher Education, 2(1), 25-34.

Stratford, M. (2015). Fallout from Corinthian collapse. Inside Higher Ed. https://www.insidehighered.com/news/2015/04/28/education-department-defends-corinthian-collapsedemocrats-turn-pressure

Taylor, S. E. (2013). Changes in doctoral education: Implications for supervisors in developing early career researchers. International Journal for Researcher Development, 3(2), 118-138.

http://dx.doi.org/10.1108/17597511311316973

Thelin, J. R. (2007). Expectations and reality in American higher education. Thought \& Action, 59-70. http://www.nea.org

Thelin, J. R. (2013). Success and excess: The contours and character of American higher education since 1960. Society, 50(2), 106-114. doi:http://dx.doi.org/10.1007/s12115-013-9630-8

Thurgood, L., Golladay, M. J., \& Hill, S. T. (2006). U.S. doctorates in the 20th century: Special report. Arlington, VA: National Science Foundation. 
United States Department of Education. (2014). Department of Education Strategic Plan for Fiscal Years 2014-2018. http://www2.ed.gov/about/reports/strat/index.html

University of Canterbury. (2015). Postgraduate prospectus.

http://www.canterbury.ac.nz/publications/postgrad.shtml

Walker, G. E., Golde, C. M., Jones, L., Bueschel, A. C., \& Hutchings, P. (2008). The formation of scholars: Rethinking doctoral education for the twenty-first century. Volume 11. San Francisco, CA: The Carnegie Foundation for the Advancement of Teaching, Jossey-Bass.

Wellington, J., \& Sikes, P. (2006). "A doctorate in a tight compartment": Why do students choose a professional doctorate and what impact does it have on their personal and professional lives? Studies in Higher Education, 31(6), 723-734. doi: 10.1080/03075070601004358

Wolcott, Harry F. (2003). The Man in the Principal's Office: An Ethnography, Updated Edition. New York: Alta Mira Press.

XE Currency Converter [Free online currency converter]. (2015). http://www.xe.com/currencyconverter/ 


\section{KEY TERMS AND DEFINITIONS}

Accessibility to Doctoral Education: Low barriers to doctoral program entry in terms of geography, affordability, and non-discriminatory entrance requirements.

Competencies: Expert subject knowledge and transferable skills in research, writing, communication, collaboration, learning partnerships, presentations, problem-solving, and project-management that doctorate-degree holders acquire through doctoral education.

Completion Rates: The percentage of first-year entrants in a doctoral program who remain in a program until obtaining a doctoral degree. Completion rates are used in doctoral educational research to identify needs for program enhancements and reform.

Contingent Academic Labor: Faculty who are hired as part-time or adjunct, full-time non-tenure track, or postdoctoral teachers or research fellows with teaching responsibilities. Contingent faculty may have long-term relationships with a host institution or may have short-term, occasional contracts.

Cultural Competencies: The development of cultural diversity awareness and skills which permit doctorate holders to work effectively in cross-cultural situations.

Digital Transformation: Changes associated with the application of digital technologies in human society.

Doctorate: The highest degree awarded by an educational institution such as a professional doctorate (e.g., DMD, EdD, JD, MD, PharmD, PsyD) or a traditional doctorate of an academic nature (PhD) conferred for original contributions to knowledge.

Globalization: A complex integration of capital, technology, and information across national boundaries; the integration of global economies, transportation, communication, and related infrastructure to promote free trade, free flow of capital, and access to foreign talent.

Online Doctoral Education: A distance-learning approach to doctoral education under the oversight of an educational institution that offers two-way communication between professors and doctoral students. Online doctoral education programs use the Internet and digital tools such as learning management systems, online libraries, e-authoring software, group collaboration software, digital file storage and sharing, discussion boards, social media, video communication, podcasts, research management software, and webinars for communication and collaboration, and for synchronous and asynchronous learning.

Tertiary Education: Education pursued beyond the high school level including associate degrees, bachelors' degrees, masters' degrees and doctorate degrees. The term tertiary education is often used synonymously with the term higher education. 